\title{
CHARACTERISTICS OF TREES ACCORDING TO COMMUNITY POPULATION LEVEL AND BY LAND USE IN THE U.S. MIDWEST
}

\author{
by Valasia lakovoglou', Jan Thompson', and Lee Burras ${ }^{2}$
}

\begin{abstract}
Long-term urban tree growth is crucial because of the need for tree-derived benefits and high placement costs. This study was conducted in five U.S. midwestern states to examine how tree characteristics are related to community population level and land-use type. Age, height, diameter, and average growth rates for the last decade were measured on 328 trees. When evaluated in terms of community population, trees in rural parks were older than trees in small, medium, and large towns. Adjusted mean growth rate was lower in rural parks than in small, medium, and large towns. When evaluated in terms of land use, both mean age and mean growth rate were higher for trees in city parks than in commercial sites. Trees in residential areas had intermediate age, size, and growth rate characteristics. Of the five species studied, silver maple, honeylocust, and hackberry performed well in a variety of settings.
\end{abstract}

Key Words. Growth rate; age-growth rate relationships; tree performance; increment core analysis.

It is often suggested that urban environments are stressful for trees because they differ from forest environments with respect to a number of factors. As Whitlow and Bassuk (1987) and Nowak and McBride (1991) have pointed out, the types of stress imposed in urban settings differ from those of forest environments, although the magnitude of stress has not been shown to be different. Owing to the complexity and interrelated nature of different environmental stress factors that may affect urban trees, previous researchers have suggested the use of tree performance to evaluate the impact of site on urban trees (e.g., Whitlow and Bassuk 1987; Neal and Whitlow 1997). Easily identified urban characteristics, such as population level and different types of land use, may be related to environmental stress and could be used to extend this approach beyond specific site analyses.

There has been little research done to systematically compare tree performance according to human population levels and land use, although some work has analyzed tree age, size, and growth rate. Moll (1989) reported differences in tree populations between rural and urban settings, with much higher average ages for trees in rural settings (150 years) compared to city trees (32 years) using data gathered during a nationwide survey from more than 300 cities in 21 U.S. states. Based on the same data, Kielbaso and Cotrone (1989) described the diameter distribution of sampled trees, with $66 \%$ less than $30 \mathrm{~cm}$ (12 in.) in diameter and only $8 \%$ more than $60 \mathrm{~cm}$ (24 in.) in diameter. In an analysis of the urban forest structure of Chicago, Illinois, Nowak (1994) reported that only $7.5 \%$ of trees were greater than $46 \mathrm{~cm}$ (18 in.). Jo and McPherson (1985) also found that $80 \%$ to $90 \%$ of residential trees in two neighborhoods in Chicago were less than $30 \mathrm{~cm}$ (12 in.) diameter. Radial growth rates of urban trees also appeared to vary according to city size. In general, radial growth rates reported for rural forest areas ranged from $1.5 \mathrm{~mm} / \mathrm{yr}$ to $12 \mathrm{~mm} / \mathrm{yr}$ for species that are common in both forested and urban areas of the Midwest (Smith and Shifley 1984; Burns and Honkala 1990; Hix and Lorimer 1996). Radial growth rates for urban areas ranged from $1.9 \mathrm{~mm} / \mathrm{yr}$ in small towns to $8 \mathrm{~mm} / \mathrm{yr}$ in large towns (Rhoads et al. 1981; Jo and McPherson 1985; Kjelgren and Clark 1992; Neal and Whitlow 1997; Rhoades and Stipes 1999). In one study that directly compared the radial growth rates of rural and urban trees, Rhoades and Stipes (1999) found greater growth rates for urban trees, which they attributed to fertilization and lack of competition on the urban sites.

Within urban settings, there is limited information available on the potential effect of land use on tree performance. Moll (1989) reported lower average age ( 7 years) for trees in downtown areas compared to the average age of trees on residential sites (32 years). Slightly greater ages (median age of 17 years) were reported by Urban (1989) for trees growing in downtown areas in 13 eastern U.S. cities. Nowak (1994) reported that institutional land dominated by buildings and residential areas in Chicago had greater proportional repre- 
sentation of large trees than did other land-use types. Kjelgren and Clark (1992) included an analysis of the effect of land use on radial growth rates for juvenile sweetgum trees in Seattle, Washington; they found higher growth rates for trees growing on park sites compared to downtown street trees and trees on a traffic island site.

The relative performance of several different species in urban settings has also been examined. Average ages vary according to historical availability of different types of plant material. For example, for residential sites in New Jersey and New York, average ages for London planetrees (39 years) and Norway maples (48 years) were much lower than that reported for silver maples (73 years) (Richards 1979; Polanin 1991). Rhoads et al. (1981) evaluated 15 different species in street tree plantings in Philadelphia, finding most rapid radial growth for American elm (Ulmus americana cv Augustine, "Augustine ascending elm"), Chinese elm, Japanese scholar tree, and willow oak. Diameter growth rates ranging from $2.8 \mathrm{~mm} /$ yr for Alaskan white cedar to $13.4 \mathrm{~mm} / \mathrm{yr}$ for northern red oak were reported by Rhodes and Stipes (1999) for trees growing on a university campus in Virginia.

One key limitation of previous research is that it does not clearly and systematically distinguish how community population level and land use were related to tree performance. In addition, few studies analyzed the performance of common midwestern urban forest species. Our study was conducted to systematically examine how four different community population levels and three different land uses are related to tree growth and condition for five midwestern species. Population levels included rural parks, small towns ( 500 people), medium towns $(\sim 5,000$ people $)$, and large towns $(\sim$ 50,000 people). Land uses were city park, residential, and commercial. Species were silver maple (Acer saccharinum L.), honeylocust (Gleditsia triacanthos L.), hackberry (Celtis occidentalis L.), black maple (Acer nigrum Michx. F.), and basswood (Tilia americana L.). We hypothesized that tree growth rate would decrease as population increased due to stress induced by deviation from natural ecosystem characteristics. Among land uses, we hypothesized that there would be a relationship between the level of human impact on a site and tree performance-that intense land uses would be associated with decreased tree growth compared to more natural city park sites. We also hypothesized that species adapted to disturbance (e.g., silver maple) would perform better on a variety of different site types.

\section{MATERIALS AND METHODS Study Area and Site Selection}

The study area included Illinois, Iowa, Minnesota, Missouri, and Wisconsin. Sites were between $45^{\circ} 34^{\prime} \mathrm{N}$ and $38^{\circ} 42^{\prime} \mathrm{N}$ latitude, and between $87^{\circ} 45^{\prime} \mathrm{W}$ and $94^{\circ} 02^{\prime} \mathrm{W}$ longitude. The sampling protocol used "clusters" of towns, each composed of two rural parks, two small towns (approximate population of 500), two medium towns (population of 5,000 ), and one large town (population of 50,000). One cluster was sampled in Illinois, Minnesota, Missouri, and Wisconsin, and two clusters were sampled in Iowa. The large town in each cluster was randomly selected from a list of towns in each state with an approximate population of 50,000. In order to minimize geographic and climatic variability within each cluster, other sampled locations were randomly selected from lists of towns with appropriate population levels within a $45-\mathrm{km}(28-\mathrm{mi})$ radius of the largest town. Each municipality was contacted by letter and by telephone in advance of fieldwork, and permission was obtained to collect samples. All samples were collected between May and September 1999.

Within each community, sites were randomly selected within specific land uses using city maps. For large and medium towns, trees in commercial and residential districts as well as from city parks were sampled. In small towns, only trees in residential and city park sites were sampled, due to absence of trees in commercial districts.

City park sites were city-designated park/recreation areas (Figure 1a). Mowed lawn (evidence of maintenance) was the primary criterion for site selection within city parks. Residential sites were areas of singlefamily housing with yards (Figure 1b). Commercial sites were areas surrounded by sidewalks, parking lots, or other commercial amenities with businesses extending at least one city block in each direction (Figure 1c).

\section{Selection of Sample Trees}

To control biological variability, only five species-silver maple, honeylocust, hackberry, black maple, and basswood-were sampled. These species were chosen because of their broad geographical ranges, abundance in the study area (Preston 1989), representation in the urban forests of the area (Schoon 1993), and general good health. Species exhibiting decline symptoms (the ashes) or susceptible to disease transmission using the increment borer (the oaks) were avoided. Although sites were randomly chosen, the largest, healthiest, and most open-grown trees on those sites were preferen- 

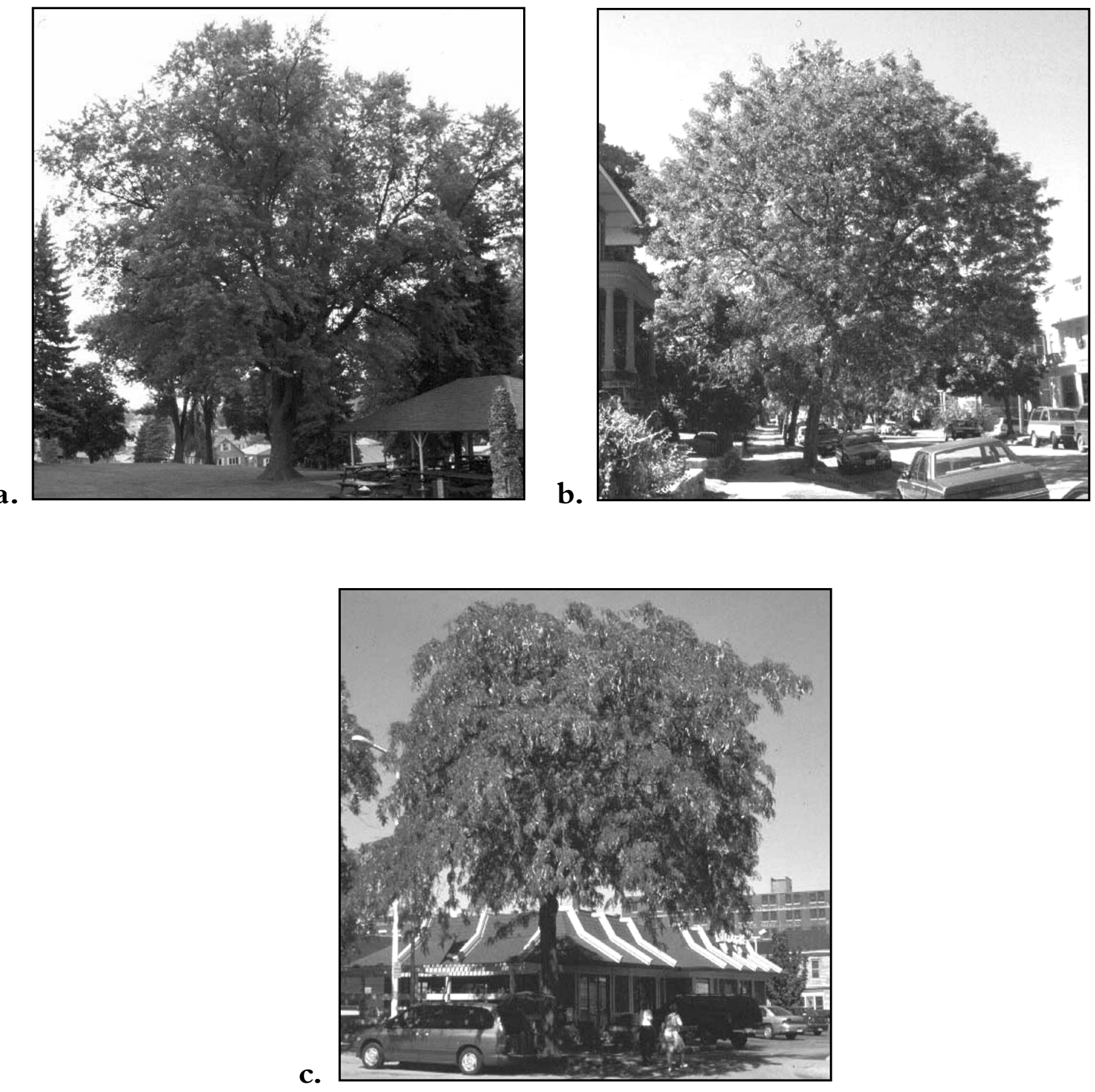

Figure 1. Representative sites for a large town (Dubuque) in Iowa. (a) City park, (b) residential area, and (c) commercial site.

tially sampled, and among species silver maple was preferentially sampled (up to $50 \%$ representation). These criteria were imposed to minimize extraneous factors (other than site) that might influence growth and to provide data for in-depth analysis of a single species across all sites. Four to six trees per land use within each town were selected.

\section{Measurements of Sample Trees and Tree Core Collection}

Tree height and diameter at $1.37 \mathrm{~m}(4.5 \mathrm{ft} \mathrm{dbh})$ were recorded for each tree. Height and dbh were measured using a clinometer and a diameter tape, respectively.

Tree cores were extracted from each tree at dbh using a handheld 5-mm (0.2-in.) diameter increment 
borer following the method described by Phipps (1985). Cores up to $61 \mathrm{~cm} \mathrm{(24} \mathrm{in.)} \mathrm{long} \mathrm{were} \mathrm{collected.}$ Cores were stored in 5-mm plastic straws in a chilled cooler (field) or freezer (laboratory). Cores were airdried, glued in wooden trays, and smoothed with finegrade sandpaper. Ring width measurements were done manually using a magnifying lamp and digital calipers. When rings were difficult to distinguish, a photo-microscope was used and cores were moistened to increase visibility of annual rings.

Tree age was determined for cores reaching the pith. When cores did not reach the pith, an estimate of age was made by dividing the tree diameter by the mean ring width of all measured years. Ring width data for the last ten years were used to compare growth rates between community population levels and different land uses.

\section{Data Analysis}

This study used a stratified sampling design. Each cluster represented a stratum, and class variables were the selected community population levels and land uses. Ring width measurements were log-transformed to reduce the effect of age on ring width (Cook 1987). The general linear models (GLM) procedure of the Statistical Analysis System (SAS Institute Inc. 1996) was used to describe and compare mean values of all tree characteristics that were adjusted to accommodate an unbalanced sample size between clusters. For example, the descriptive mean age of 60 years for silver maple in rural settings was adjusted to 62 years to allow comparison in the model for age according to population level, a change of $3 \%$. The types of adjustment required for all models are indicated where

Table 1. Number of sampled trees by species across the community population gradient and land use. Row totals indicate the total number of trees sampled in each community and land use, and column totals indicate the total number of sampled trees for each species. For land use, parks include only city parks.

\begin{tabular}{|c|c|c|c|c|c|c|c|}
\hline \multirow{2}{*}{$\begin{array}{l}\text { Gradient } \\
\text { Community } \\
\text { population }\end{array}$} & \multirow[b]{2}{*}{$\begin{array}{l}\text { Total \# } \\
\text { of sites }\end{array}$} & \multicolumn{5}{|c|}{ Number of trees of each species } & \multirow[b]{2}{*}{$\begin{array}{l}\text { Total \# } \\
\text { of trees }\end{array}$} \\
\hline & & $\begin{array}{l}\text { Silver } \\
\text { maple }\end{array}$ & Honeylocust & Hackberry & $\begin{array}{l}\text { Black } \\
\text { maple }\end{array}$ & Basswood & \\
\hline Rural park & 12 & 9 & 7 & 12 & 8 & 8 & 44 \\
\hline Small town & 11 & 42 & 6 & 10 & 15 & 3 & 76 \\
\hline Medium town & 12 & 57 & 27 & 15 & 14 & 12 & 125 \\
\hline Large town & 6 & 32 & 34 & 8 & 2 & 7 & 83 \\
\hline Total & 4 & 140 & 74 & 45 & 39 & 30 & 328 \\
\hline$\underline{\text { Land use }}$ & $\begin{array}{l}\text { Total \# } \\
\text { site type }\end{array}$ & & & & & & \\
\hline City park & 26 & 55 & 23 & 20 & 7 & 6 & 111 \\
\hline Residential & 29 & 63 & 12 & 13 & 16 & 12 & 116 \\
\hline Commercial & 15 & 13 & 32 & 0 & 8 & 4 & 57 \\
\hline Total & 70 & 131 & 67 & 33 & 31 & 22 & 284 \\
\hline
\end{tabular}

marginal means are presented (Littell et al. 1991). Multiple comparisons were done by evaluating $p$ values for all pairs of means for both population level (trees sampled in rural parks, and small, medium, and large towns) and by land use (commercial, residential, and park) (Bowerman and O'Connell 1990). Separate species analyses (resulting in different marginal mean values according to necessary adjustment in the models) were also done using pairwise comparisons. Statistical significance was determined for comparisons with $p<0.05$.

\section{RESULTS}

Three hundred twenty-eight trees were sampled (Table 1). Silver maple was the most common species sampled (43\%), although predominant species varied somewhat according to community population level and land use (Table 1). Trees over $30 \mathrm{~cm}$ (12 in.) diameter constituted $80 \%$ of the sample population. Detailed results for tree performance across the two gradients are presented first, followed by a comparison of performance for three of the sampled species.

\section{Characteristics of Trees Sampled According to Community Population Level}

The age range across the community population gradient for trees sampled in rural park sites was 16 to 148 years; for trees in small and medium towns it was 9 to 144 years and 7 to 130 years, respectively; for trees in large towns it was 10 to 144 years.

As community population level increased, sampled trees were younger, shorter, and had smaller diameters (Figure 2).

Application of the statistical model to examine the population level gradient to two individual species (silver maple and honeylocust), however, indicated that silver maple deviated from the general pattern observed, with no significant differences in age or diameter along the population gradient (Figure 2). 
a.
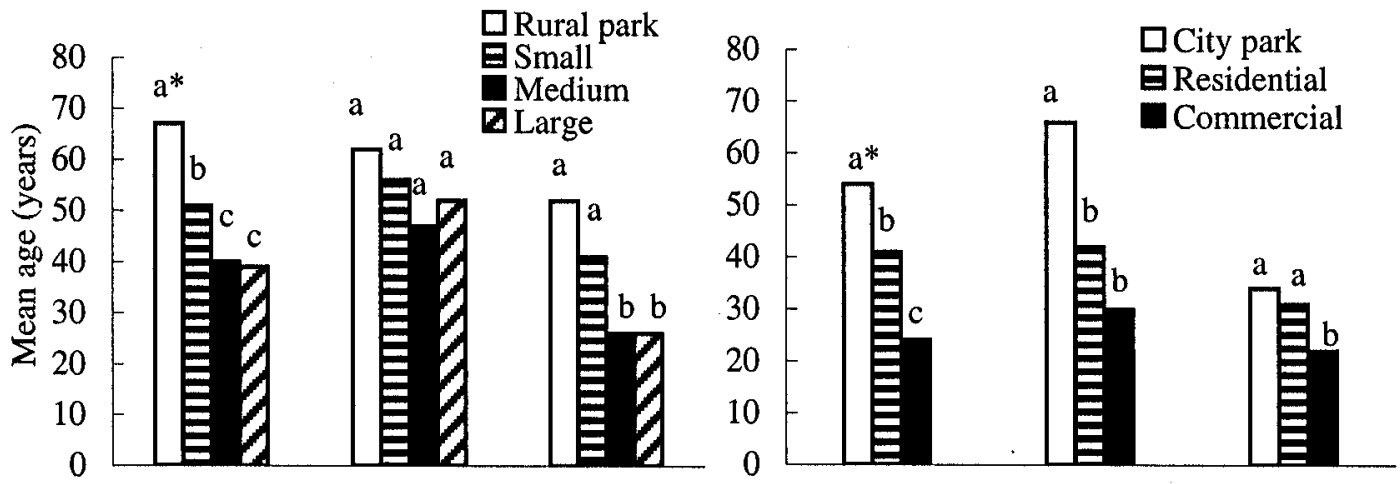

e.
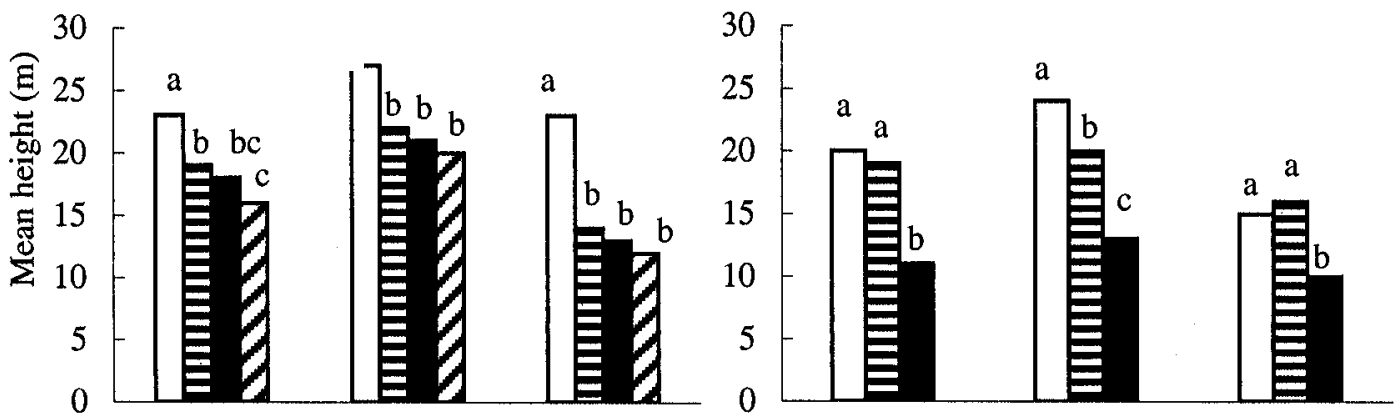

b.
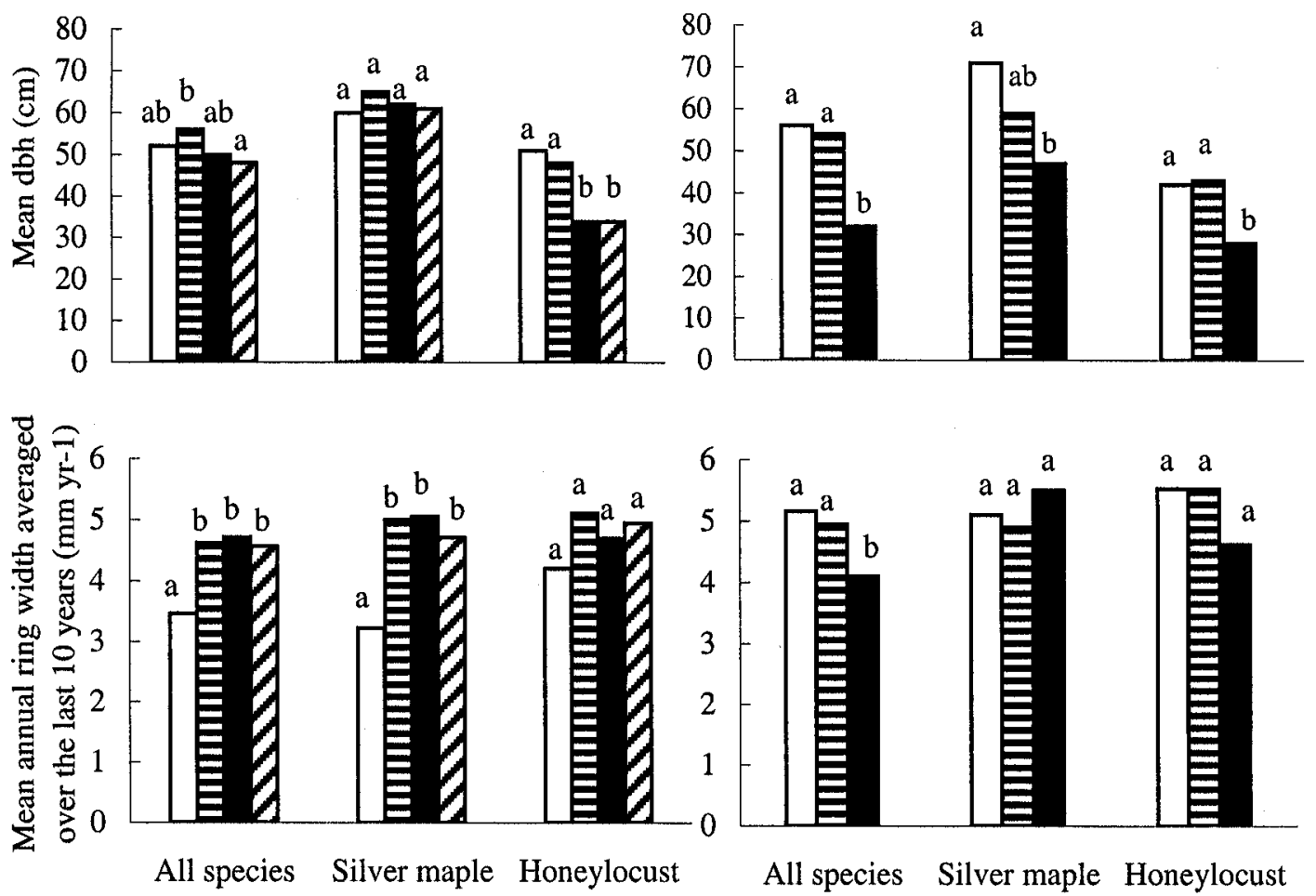

h.

\section{d.}

All species Silver maple Honeylocust

All species Silver maple Honeylocust

Figure 2. (a) Mean age, (b) height, and (c) diameter (adjusted for cluster) and (d) mean annual ring width over the past 10 years (also adjusted for age) for all species, silver maple, and honeylocust for community population levels; and (e) mean age, (f) height, and (g) diameter (adjusted for cluster) and (h) mean annual ring width over the past 10 years (also adjusted for age) for all species, silver maple, and honeylocust for land use. "Means with the same letter are not significantly different at $p<0.05$. 
Adjusted mean annual ring width, averaged over the past 10 years for all species, was smaller for trees in rural parks than those in small, medium, and large towns (Figure 2). There were no differences between small, medium, and large towns. Application of the statistical model for population level in this case indicated that silver maple also had lower growth rates in rural parks compared to all town sizes. Honeylocust showed no differences in ring width along the population gradient. The effect of age on mean annual ring width averaged over the past 10 years for the overall analysis was significant, even though the ring width data were logtransformed for data analysis; greater ring widths were consistently associated with younger trees: $\ln (\mathrm{rw})=$ $-0.0108 x+1.9967 ; \mathrm{r}^{2}=0.38$.

\section{Characteristics of Trees by Land Use}

The age range for trees sampled in city parks was 7 to 144 years, for trees on residential sites it was 9 to 144 years, and for trees on commercial sites it was 9 to 69 years.

As land use changed from park and residential to commercial, sampled trees were younger, shorter, and had smaller diameters (Figure 2). When the statistical model for the land-use gradient was applied to all species and to a single species (honeylocust), height and diameter of trees on residential sites were not different from those in city parks.
Adjusted mean annual ring width averaged over the last 10 years for all species was greater for trees in city parks and in residential sites compared to commercial sites (Figure 2). When the land-use model was applied to single species, there were no significant differences in growth rates for silver maple or honeylocust (Figure 2). Again, the effect of age was significant, even though the ring width data were log-transformed for data analysis; greater ring widths were associated with younger trees.

\section{Comparison of Species}

Overall adjusted mean age was greater for black maple than for honeylocust, basswood, or hackberry (Table 2). Adjusted mean height and diameter of silver maple were greater than those of all other species. Adjusted mean ring width over the past 10 years for silver maple was also greater than that of black maple and honeylocust.

Table 2. Overall comparison of species based on means (adjusted for cluster, town, size, and land use) for age, height, diameter, and ring width (also adjusted for age).

\begin{tabular}{llllll}
\hline Species & $\mathrm{N}$ & Age & Height & Diameter & Ring width \\
\hline Silver maple & 140 & $53 \mathrm{ac} *$ & $21.1 \mathrm{a}$ & $60.4 \mathrm{a}$ & $4.8 \mathrm{a}$ \\
Honeylocust & 74 & $36 \mathrm{~b}$ & $15.8 \mathrm{~b}$ & $40.4 \mathrm{~b}$ & $3.9 \mathrm{~b}$ \\
Hackberry & 45 & $44 \mathrm{cb}$ & $16.7 \mathrm{~b}$ & $44.1 \mathrm{~b}$ & $4.2 \mathrm{ab}$ \\
Black maple & 39 & $58 \mathrm{a}$ & $16.1 \mathrm{~b}$ & $43.2 \mathrm{~b}$ & $3.6 \mathrm{~b}$ \\
Basswood & 30 & $41 \mathrm{~b}$ & $14.8 \mathrm{~b}$ & $41.3 \mathrm{~b}$ & $4.3 \mathrm{ab}$ \\
\hline
\end{tabular}

${ }^{*}$ Means within a column with the same letter are not statistically different at $p<0.05$.

Table 3. Radial growth rates $(\mathrm{mm} / \mathrm{yr})$ reported in the literature (sources noted as footnotes below table) and documented during this study in different settings for five species common in the midwestern United States. Some published diameter growth rates were converted to radial growth for ease of comparison.

\begin{tabular}{|c|c|c|c|c|c|c|c|c|}
\hline \multirow[b]{2}{*}{ Species } & \multicolumn{4}{|c|}{ Published growth rates $(\mathrm{mm} / \mathrm{yr})$} & \multicolumn{4}{|c|}{ Measured growth rates $(\mathrm{mm} / \mathrm{yr})$} \\
\hline & $\begin{array}{l}\text { Rural } \\
\text { areas }\end{array}$ & $\begin{array}{l}\text { Urban } \\
\text { small }\end{array}$ & $\begin{array}{l}\text { Urban } \\
\text { medium }\end{array}$ & $\begin{array}{l}\text { Urban } \\
\text { large }\end{array}$ & $\begin{array}{l}\text { Rural } \\
\text { parks }\end{array}$ & $\begin{array}{l}\text { Urban } \\
\text { small }\end{array}$ & $\begin{array}{l}\text { Urban } \\
\text { medium }\end{array}$ & $\begin{array}{l}\text { Urban } \\
\text { large }\end{array}$ \\
\hline Silver maple & $7-12^{z}$ & & & & $1.3-4.7$ & $1.1-14.4$ & $0.7-16.5$ & $1.7-7.0$ \\
\hline Basswood & $\begin{array}{l}1.5-2.4^{z} \\
2.2^{y}\end{array}$ & & & & $0.8-3.9$ & $5.7-11.0$ & $3.3-9.7$ & $2.8-7.2$ \\
\hline Hackberry & $2.5-4.0^{z}$ & & & & $1.1-9.4$ & $2.0-9.7$ & $1.7-13.3$ & $2.6-7.4$ \\
\hline Honeylocust & $4-6.5^{z}$ & & & $7.9^{\mathrm{w}}$ & $1.1-7.4$ & $2.9-6.7$ & $2.3-11.8$ & $2.3-9.0$ \\
\hline Black maple & $3.2^{z}$ & & & & $1.0-4.5$ & $1.0-7.9$ & $1.6-7.8$ & $5.2-5.4$ \\
\hline Other species & $4.0^{\mathrm{s}}$ & $1.9^{\mathrm{x}}$ & & $\begin{array}{l}4.0-8.0^{\mathrm{v}} \\
2.1-7.9^{\mathrm{u}} \\
5.5^{\mathrm{t}}\end{array}$ & & & & \\
\hline
\end{tabular}

${ }^{2}$ Burns and Honkala 1990

'Hix and Lorimer 1996.

x Rhoades and Stipes 1999 (nine different species, Virginia Tech campus site).

"Rhoads et al. 1981.

vNeal and Whitlow 1997 (willow oak).

"Kjelgren and Clark 1992 (sweetgum).

Jo and McPherson 1995 (average for young (<30 cm dbh) hardwood species including maple, elm, honeylocust, mulberry, crabapple, ash).

sSmith and Shifley 1984 (mean diameter growth for hardwood species in Illinois and Indiana forests). 
Both the range of measured ring widths and the greatest values for ring widths of trees sampled in towns in this study were greater than those we measured in rural parks or found reported in the literature for trees growing in natural stands (Table 3). However, measured ringwidth values are consistent with those previously reported for urban trees (Table 3 ).

\section{Characteristics of Species According to the Two Gradients}

A statistical model for species comparison was applied for each community size and land use including all species, but only the three most common species sampled are reported here: silver maple, honeylocust, and hackberry (Table 4). When tree ages were compared according to population level, silver maple and hackberry were older than honeylocust sampled in medium and large towns (Table 4). Silver maple sampled in city parks were also older than honeylocust. For all town sites sampled along both gradients, silver maple had consistently greater height and diameter than did honeylocust. There were no differences between species in adjusted mean ring width for the last 10 years in rural parks or large towns (Table 4). Silver maple had greater adjusted mean ring widths than did honeylocust in small and medium towns and in city parks and commercial areas. In residential areas, silver maple had greater mean ring widths than did hackberry (Table 4).

\section{DISCUSSION}

Community population levels and land uses were each related to tree growth, although our initial hypotheses were not all validated. Our hypothesis that higher community population levels would be associated with reduced growth rates of trees was not supported. In fact, we found the opposite to be true-as community population level increased, mean radial growth rates also increased. Our hypothesis that city park sites would be associated with greater growth rates compared to commercial sites was validated. Lastly, our hypothesis that disturbance-adapted species such as silver maple would perform better on a variety of site types was found to be true.

Although site selection was done randomly for this study, individual tree selection criteria were such that the sample population reported on here is composed of larger, older trees ( $80 \%$ were $>30 \mathrm{~cm}$ diameter) compared to earlier reports for urban tree populations $(60 \%$ to $80 \%$ of trees $<30 \mathrm{~cm}$; e.g., Kielbaso and Cotrone 1989, Jo and McPherson 1995). Although this precludes some analyses, our objective of sampling the healthiest specimens at any given site was met. Our results and interpretation are limited to site comparisons, and the sample population reported here should not considered representative of actual urban forests.

The adjusted mean age of trees sampled was youngest in large towns, intermediate in small towns, and oldest in rural parks. These data for the Midwest corroborate trends reported earlier by Moll (1989) and Kielbaso and Cotrone (1989). Our interpretation is that the predominance of younger trees 
in large towns is largely due to relatively recent tree planting associated with urban redevelopment and/or expansion. For example, according to census data, Coon Rapids (the large town sampled in Minnesota) has experienced a $420 \%$ increase in population over the past 40 years (from 14,931 residents in 1960 to 62,790 residents in 1996). Alternatively, the lower average age of trees in more highly populated communities could indicate reduced lifespan, although our study did not include examination of mortality.

Adjusted growth rates averaged over the past 10 years clearly indicate that trees in rural parks have been growing more slowly than trees on city sites. These results corroborate at a regional scale the earlier findings of Rhoades and Stipes (1999), who found reduced radial growth rates for trees in rural areas compared to urban settings in and near Blacksburg, Virginia. Reduced growth rates in our study are partly attributable to greater mean age of rural trees, even though the data were $\log$-transformed to reduce that effect. Although an attempt was made to sample open-crown trees, there were a greater number of potentially competitive trees in the rural parks, which may be related to radial tree growth in those settings (Iakovoglou 2001).

For trees sampled according to land use, those in city parks were oldest, residential areas were intermediate, and those in commercial sites were youngest. These trends were consistent with previous reports for street trees (Mo11 1989; Foster and Blaine 1978), although previously reported age values for downtown sites were considerably less (7 years and 10 years, respectively). The mean age of these trees reflects relatively recent planting. However, our data also indicate that early mortality on downtown sites may be avoidable. The range in age for trees in commercial settings in our study was from 9 to 69 years, indicating the potential for much greater longevity than is typically believed to be true for downtown environments. Continued investment in seeking better ways to install and manage trees for potentially long lives in commercial districts is worthwhile.

Even though commercial trees were young, they had lower mean growth rates compared to residential and city park trees (Figure 2). Kjelgren and Clark (1992) reported similar findings for juvenile sweetgum trees in Seattle, Washington. Since age was not the cause for reduced growth rates on commercial sites, other siterelated factors appear to cause unfavorable conditions for tree growth. This provides evidence that downtown settings are limiting long-term tree growth compared to other land-use types in the Midwest.

The relative performance of the three species most thoroughly evaluated on different site types in this study could be summarized by generally examining the age-growth rate relationships for each species along both of the gradients analyzed. This interpretation is based on fewer available data points (Table 3). Overall, mean tree age decreased with increasing community population and increasing intensity of land use (Figure 2). A concomitant increase in radial growth rate could be expected if growth rate for each species was due simply to age, which was a significant factor in the overall analysis (an expected scenario is shown in Figure $3 \mathrm{a}$ ). For the town size gradient, silver maple and honeylocust generally follow this pattern (Figure 3b). Although less data are available, hackberry differs from the expected relationship since it has significantly greater growth rates in large towns even though there is not a consistent trend in age along the population gradient for this species (Figure 3b). Considering land-use types, silver maple exhibits an expected increase in growth rate (although not statistically significant) with average age decreasing from park sites to commercial sites (Figure 3c). Differences in growth rate along the land-use gradient were not significant for honeylocust or hackberry, although growth rates for these species were generally lowest on commercial sites in spite of the relative youth of the trees (Figure 3c). This analysis suggests that silver maple, honeylocust, and hackberry could be expected to grow well in urban settings regardless of city size. In addition, it is evident that silver maple grows rapidly even under relatively intense land-use situations where the other species examined in this study do not.

\section{PRACTICAL APPLICATIONS}

Characteristics of this sample population suggest that trees can perform well in all of the settings we examined. Thus, while good management practices are a must, no particular locale should be deemed unsuitable for trees without a thorough site investigation. In addition, previously reported urban tree demographics, based on average ages and sizes, may undersell the potential of some sites to support long-term tree growth. Based on our study, trees can thrive under the proper conditions even in large cities and with intensive land uses for 70 to 100 years. Since benefits that accrue from these trees increase dramatically as the trees' canopies 


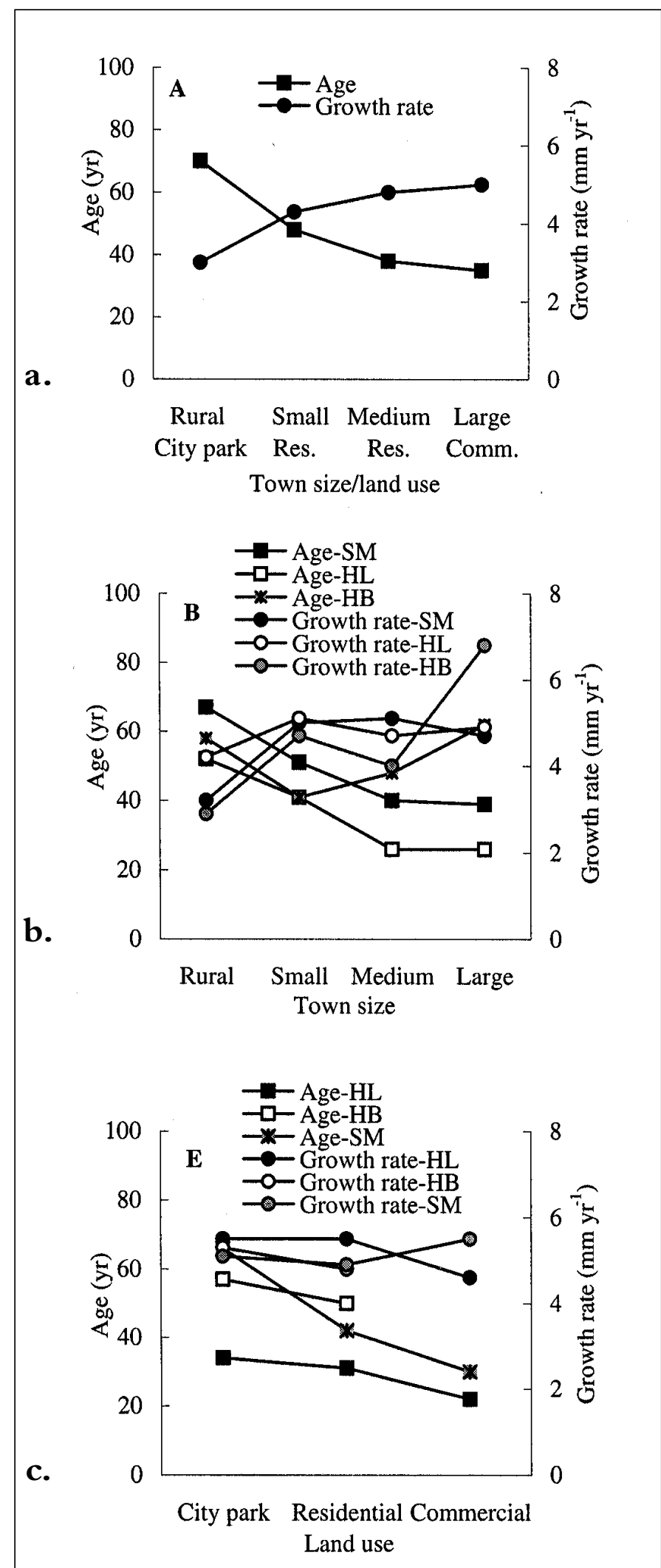

Figure 3. (a) Expected and (b, c) actual age versus growth rates for all species by community population levels (b) and by land uses (c). SM = silver maple, $\mathrm{HL}$ $=$ honeylocust, $\mathrm{HB}=$ hackberry. expand, community foresters are encouraged to plant long-lived species and maintain them to achieve maximum benefits in the long run. Finally, although structural integrity in silver maple can be problematic, this species appears to be adapted to environments with significant human disturbance. Thus, silver maple may merit serious consideration for impacted sites where rapid tree growth and canopy development are desired and adequate maintenance will be provided.

\section{LITERATURE CITED}

Bowerman, B.L., and R.T. O'Connell. 1990. Linear Statistical Models: An Applied Approach (2nd ed.). PWS-Kent Publishing Co., Boston, MA. 1024 pp.

Burns, R.M., and B.H. Honkala (Tech. Coords). 1990. Silvics of North America 2: Hardwoods. Agriculture Handbook 654, USDA-Forest Service. Washington D.C. 877 pp.

Cook, E.R. 1987. The decomposition of tree-ring series for environmental studies. Tree-Ring Bull. 47:37-59.

Foster, R.S., and J. Blaine. 1978. Urban tree survival: Trees in the sidewalk. J.Arboric. 4(1):14-17.

Hix, D.M., and C.G. Lorimer. 1990. Growth-competition relationships in young hardwood stands on two contrasting sites in southwestern Wisconsin. For. Sci. 36(4):1032-1049.

Iakovoglou, V. 2001. Trees examined along a rural-urban gradient and by local land use in the Midwest U.S.: An investigation of factors related to tree growth. M.S. thesis, Iowa State University, Ames, IA.

Jo, H.K, and E.G. McPherson. 1995. Carbon storage and flux in urban residential greenspace. J. Environ. Manage. 45:109-133.

Kielbaso, J.J., and V. Cotrone. 1989. The state of the urban forest, pp 11-18. In Proc. 4th National Urban Forestry Conference, St. Louis, MO.

Kjelgren, R.K., and J.R. Clark. 1992. Microclimates and tree growth in three urban spaces. J. Environ. Hortic. 10(3):139-145.

Littell, R.C., R.J. Freund, and P.C. Spector. 1991. SAS System for Linear Models (3rd ed.). SAS Institute, Inc., Cary, NC. 329 pp.

Moll, G. 1989. The state of our urban forest. Am. For. November/December:61-64.

Neal, B.A., and T.H. Whitlow. 1997. Using tree growth rates to evaluate urban treeplanting specifications. J. Environ. Hortic. 15(2):115-118.

Nowak, D.J. 1994. Urban forest structure: The state of Chicago's urban forest, Chapter 2. In E.G. McPherson, D.J Nowak, and R.A. Rowntree (Eds.). Chicago's Urban Forest Ecosystem: Results of the Chicago Urban Forest Climate Project. GTR NE-186. USDA Forest Service, Northeastern Forest Experiment Sta., Radnor, PA. 201 pp.

Nowak, D.J., and J.R. McBride. 1991. Comparison of Monterey pine stress in urban and natural forests. J. Environ. Manage. 32:383-395.

Phipps, R.L. 1985. Collecting, Preparing, Crossdating, and Measuring Tree Increment Cores. Water-Resource Investigation Report 85-4148. USGS, Reston,VA. 
Polanin, N. 1991. Removal history and longevity of two street tree species in Jersey City, New Jersey. J. Arboric. 17(11):303305.

Preston, R.J., Jr. 1989. North American Trees (4th ed.). Iowa State University Press, Ames, IA.

Rhoades, R.W., and R. J. Stipes. 1999. Growth of trees on the Virginia Tech campus in response to various factors. J. Arboric. 25(4):211-215.

Rhoads, A.F., P.W. Meyer, and R. Sanfelippo. 1981. Performance of urban street trees evaluated. J. Arboric. 7(5):127-132.

Richards, N. A. 1979. Modeling survival and consequent replacement needs in a street tree population. J. Arboric. 5(11):251-255.

SAS Institute, Inc. 1996. SAS/STAT User's Guide. Release 6.12. SAS Institute, Inc., Cary, NC.

Schoon, K.J. 1993. The Midwest urban tree index. J. Arboric. 19(4):230-237.

Smith,W.B., and S.R. Shifley. 1984. Diameter Growth, Survival, and Volume Estimates for Trees in Indiana and Illinois. Research Note NC-299. USDA Forest Service, St. Paul, MN.

Urban, J.R. 1989. Evaluation of tree planting practices in the urban landscape, pp 119-127. In Make Our Cities Safe for Trees: Proc. 4th Urban Forestry Conference. The American Forestry Association, Washington, DC.

Whitlow, T.H., and N.L. Bassuk. 1987. Trees in difficult sites. J. Arboric. 13(1):10-17.
Acknowledgments. Journal Paper No. J-19365 of the Iowa Agriculture and Home Economics Experiment Station, Ames, Iowa, Project No. 3413 and supported by McIntire-Stennis funds and State of Iowa funds, and by a grant from the National Urban and Community Forestry Advisory Council through the USDA Forest Service. We would like to acknowledge the field assistance of Jon Handrick, Dan Anderson, Carol LaFaver, Becky Kipper, Michael Mack, John Smith, and Nick Zaimes, and laboratory assistance of Nathan Gassman and Ashley Green. We also thank individuals (municipal personnel and home owners) in the communities involved for permission to sample trees. Finally, we thank Dr. Phil Dixon and Chunfa Jie for assistance with statistical analyses, and Dr. Willis Goudy, Dr. J. Michael Kelly, and two anonymous reviewers for their critiques of the manuscript.

${ }^{1 *}$ Department of Forestry

253 Bessey Hall

Iowa State University

Ames, IA 50011, U.S.

${ }^{2}$ Department of Agronomy

Iowa State University

Ames, IA 50011, U.S.

*Corresponding author: Jan Thompson 
Résumé. À long terme, la croissance des arbres est cruciale en raison des besoins par rapport aux bénéfices procurés par les arbres ainsi que des frais d'investissement élevés. Cette étude a été menée dans cinq états du Midwest américain afin d'examiner comment les caractéristiques des arbres sont reliées au niveau de population ainsi qu'au type d'utilisation du territoire. L'âge, la hauteur, le diamètre et le taux de croissance moyen pour la dernière décennie ont été mesurés sur 328 arbres. Lorsque évalué en terme de type de communauté, les arbres dans les parcs ruraux étaient plus grands que ceux des villes, petites ou grandes. Le taux ajusté de croissance moyenne était plus faible dans les parcs ruraux que dans les petites, moyennes ou grandes villes. Lorsque évalué en terme d'utilisation du territoire, à la fois l'âge moyen et le taux de croissance moyen étaient plus élevés pour les arbres dans les parcs urbains que sur les sites commerciaux. Les arbres dans les secteurs résidentiels avaient des caractéristiques intermédiaires d'âge, de dimensions et de taux de croissance. Des cinq espèces étudiées, l'érable argenté, le févier inerme et le micocoulier occidental étaient celles qui avaient une bonne performance dans les divers types de sites.

Zusammenfassung. Langfristige Baumpflanzungen in Städten sind unter dem Aspekt des daraus resultierenden Nutzens und der Standortkosten kritisch zu beurteilen. Diese Studie wurde in 5 US-Bundesstaaten des mittleren Westens durchgeführt, um die Baumcharakteristika in Bezug mit der Bevölkerung und der Landnutzung zu setzen. Alter, Höhe, Durchmesser und durchschnittliche Wachstumsraten wurden über die Jahre an 328 Bäumen gemessen. Bei Messungen in Bezug auf die
Bevölkerungsdichte wurde festgestellt, dass die Bäume in großen Stadtparkanlagen älter waren als in kleinen, mittleren und größeren Städten. Die angepasste mittlere Wachstumsrate war in diesen Anlagen aber geringer. In Bezug auf Landnutzung waren sowohl Durchschnittsalter als auch Durchschnittswachstumsrate bei Stadtbäumen größer als in Gewerbeanlagen. Die Bäume in Wohngegenden hatten durchschnittliche Alter-, Größen-, und Wachstumscharakteristika.Von den 5 untersuchten Spezies zeigten Silberahorn, Gleditschie und Hackberry an allen Standorten gute Ergebnisse.

Resumen. El crecimiento a largo plazo de los árboles urbanos es crucial debido a los altos costos de emplazamiento y por los beneficios derivados de los mismos. Este estudio fue realizado en cinco estados del medio-oeste de los Estados Unidos, con el fin de examinar de qué manera las características del árbol están relacionadas con el nivel de población de la comunidad y el tipo de uso del suelo. Para 328 árboles se midió la edad, altura, diámetro, tasas de crecimiento promedio para los últimos 10 años. Cuando fueron evaluados en términos de la población de la comunidad, los árboles en parques rurales fueron más viejos que los árboles en pueblos pequeños, medios y grandes. Cuando se evaluaron en términos del uso del suelo, tanto la edad media como la tasa de crecimiento fueron mayores para los árboles en parques urbanos que en sitios comerciales. Los árboles en áreas residenciales tuvieron edad intermedia, tamaño y tasa de crecimiento características. De las cinco especies estudiadas, silver maple, honeylocust y hackberry trabajaron bien en una amplia variedad de ambientes. 